\title{
Above- and Below-Ground Reserved Carbon in Danaba Community Forest of Oromia Region, Ethiopia: Implications for $\mathrm{CO}_{2}$ Emission Balance
}

\author{
Muluken Nega Bazezew ${ }^{1, ~}$, Teshome Soromessa ${ }^{2}$, Eyale Bayable $^{2}$ \\ ${ }^{1}$ College of Agriculture and Natural Resources, Dilla University, Dilla, Ethiopia \\ ${ }^{2}$ Center for Environmental Science, College of Natural Science, Addis Ababa University, Addis Ababa, Ethiopia
}

Email address:

fullday.gc2002@gmail.com (Bazezew M. N.)

\section{To cite this article:}

Muluken Nega Bazezew, Teshome Soromessa, Eyale Bayable. Above- and Below-Ground Reserved Carbon in Danaba Community Forest of Oromia Region, Ethiopia: Implications for $\mathrm{CO}_{2}$ Emission Balance. American Journal of Environmental Protection.

Vol. 4, No. 2, 2015, pp. 75-82. doi: 10.11648/j.ajep.20150402.11

\begin{abstract}
Forests can capture and retain enormous amount of carbon over long periods of time. Their role in carbon emission balance is also well documented. However, especially in developing country wide spread deforestation and forest degradation is continuing unknowingly and deliberately. This study was conducted to estimate $\mathrm{CO}_{2}$ mitigation capacity of the dry Afromontane forest of Danaba found in Oromia Regional State of Ethiopia. A systematic sampling method through Global Positioning System (GPS) was used to identify each sampling point. Results revealed that the total mean carbon density of the $\mathrm{CF}$ was $507.29\left(1861.75 \mathrm{CO}_{2}\right.$ equivalents) $\mathrm{t} \cdot \mathrm{ha}^{-1}$ whereas trees share $319.43\left(1172.31 \mathrm{CO}_{2}\right.$ equivalents $) \mathrm{t} \cdot \mathrm{ha}^{-1}$, undergrowth shrubs $0.40\left(1.47 \mathrm{CO}_{2}\right.$ equivalents) $\mathrm{t} \cdot \mathrm{ha}^{-1}$, litter, herbs and grasses (LHGs) $1.06\left(3.89 \mathrm{CO}_{2}\right.$ equivalents) $\mathrm{t} \cdot \mathrm{ha}^{-1}$ and soil organic carbon (SOC) 186.40 (684.09 $\mathrm{CO}_{2}$ equivalents) $\mathrm{t} \cdot \mathrm{ha}^{-1}$ (up to $30 \mathrm{~cm}$ depth). The ultimate result implies that Danaba CF is a reservoir of high atmospheric $\mathrm{CO}_{2}$. To enhance sustainability of the forest potentiality, the carbon sequestration should be integrated with Reduced Emission from Deforestation and Degradation $\left(\mathrm{REDD}^{+}\right)$and Clean Development Mechanism $(\mathrm{CDM})$ carbon trading system of the Kyoto Protocol to get monetary benefit of $\mathrm{CO}_{2}$ mitigation.
\end{abstract}

Keywords: Carbon Sequestration, Climate Change, Community Forest, Geo-Position, Mitigation

\section{Introduction}

Forests are known to play an important role in regulating the global climate. The response of forests to the rising of atmospheric $\mathrm{CO}_{2}$ concentrations is crucial for the global carbon cycle as they have huge potential in sequestering and storing more carbon than any terrestrial ecosystem [1]. Though the role of forests in climate change mitigation is widely recognized, the recent assessment shows carbon stocks in forest biomass decreased by an estimated 0.5 gigatonne annually during the period 2005-2010 because of a reduction in the global forest area [2]. Loss of forest biomass through deforestation and forest degradation makes up 12 to $20 \%$ of annual greenhouse gas emission, which is more than all forms of transportation combined [3]. Especially, in Africa forest degradation is very high compared to the rest of the world.

Ethiopia is facing rapid deforestation and degradation of forest resources and experiencing the effects of climate change such as an increase in average temperature, and rainfall pattern variability, and is one of most vulnerable countries to climate change [4]. As Ethiopia is dependent on natural resources and agriculture, it is less able to cope with the shocks of climate change-induced droughts, floods, soil erosion and other natural disasters. People will find it hard to escape poverty if vulnerability to climate change persists. The Government of the Federal Democratic Republic of Ethiopia has therefore implemented National REDD $^{+}$ working document in 2008 and Climate Resilience Green Economy (CRGE) Framework in 2011 by means of protecting and re-establishing forests for their economic, ecosystem services and carbon storage. Even if the strategic frameworks focus on carbon emission management, Ethiopia does not have carbon accumulation records and databank to monitor and enhance carbon sequestration potential of different forests.

Working in CFs would have high importance in achieving carbon sequestration and conservation of biodiversity on the 
one hand, and empowering communities to take part and improve their living condition on the other hand since state owned forests are unsuccessful in their sustainability in the past decades. Since many Ethiopian people are living close to forests, the relationship of these people to forests has to be taken as an opportunity for spreading CFs to improve carbon sequestration.

An integrated forest management approach has been initiated in 2000 and named Forest Dwellers Association in Danaba community forest (CF). Danaba CF is heavily exploited remnant coniferous forests found in West-Arsi Zone of Oromia Regional State of Ethiopia. Ongoing threats of observed human activities such as agricultural expansion, livestock grazing, illegal charcoal production and harvesting for firewood and construction which will likely diminish all carbon pools unless effective measures are enforced.

Therefore, the study was designed to estimate the reserved biomass carbon in trees, shrubs, LHGs and soil of Danaba CF which would have high important as an information basis that can create the environment to attract climate change mitigation finances and so to expand and conserve CFs in Ethiopia.

\section{Material and Methods}

\subsection{Study Area}

Danaba $\mathrm{CF}$ is a 5437 ha forest that belongs to AdabaDodola CF priority areas under the administrative of Community Forest User Groups (CFUGs). The area is located in West Arsi Zone of Oromia National Regional State located 5-11 km South-East of Dodola town and $320 \mathrm{~km}$ South-East of Addis Ababa, Ethiopia (Figure 1). It lies between $06^{\circ} 54^{\prime} 20^{\prime \prime} \mathrm{N}$ and $6^{\circ} 54^{\prime} 3^{\prime \prime} \mathrm{N}$ latitude and between $39^{\circ} 8^{\prime} 19^{\prime \prime} \mathrm{E}$ and $39^{\circ} 13^{\prime} 50^{\prime \prime} \mathrm{E}$ longitude with an elevation ranging between 2490-3218 m a.s.l. According to Ethiopian National Meteorology agency weather data from 1995-2013, the mean minimum and maximum temperature of the study area is $3.6^{\circ} \mathrm{C}$ and $24.3^{\circ} \mathrm{C}$, respectively. The mean annual rainfall is $964 \mathrm{~mm}$, of which $70-80 \%$ received in main wet season of June to early September and 20-30\% from remaining less pronounced wet periods. Vegetation of Danaba CF falls under dry-evergreen montane forest with strongly dominated by Juniperus procera and Podocarpus falcatus species. The soil in most part of the study area is Luvisols type with Cherozem occurring in some place at lower altitudes [5].
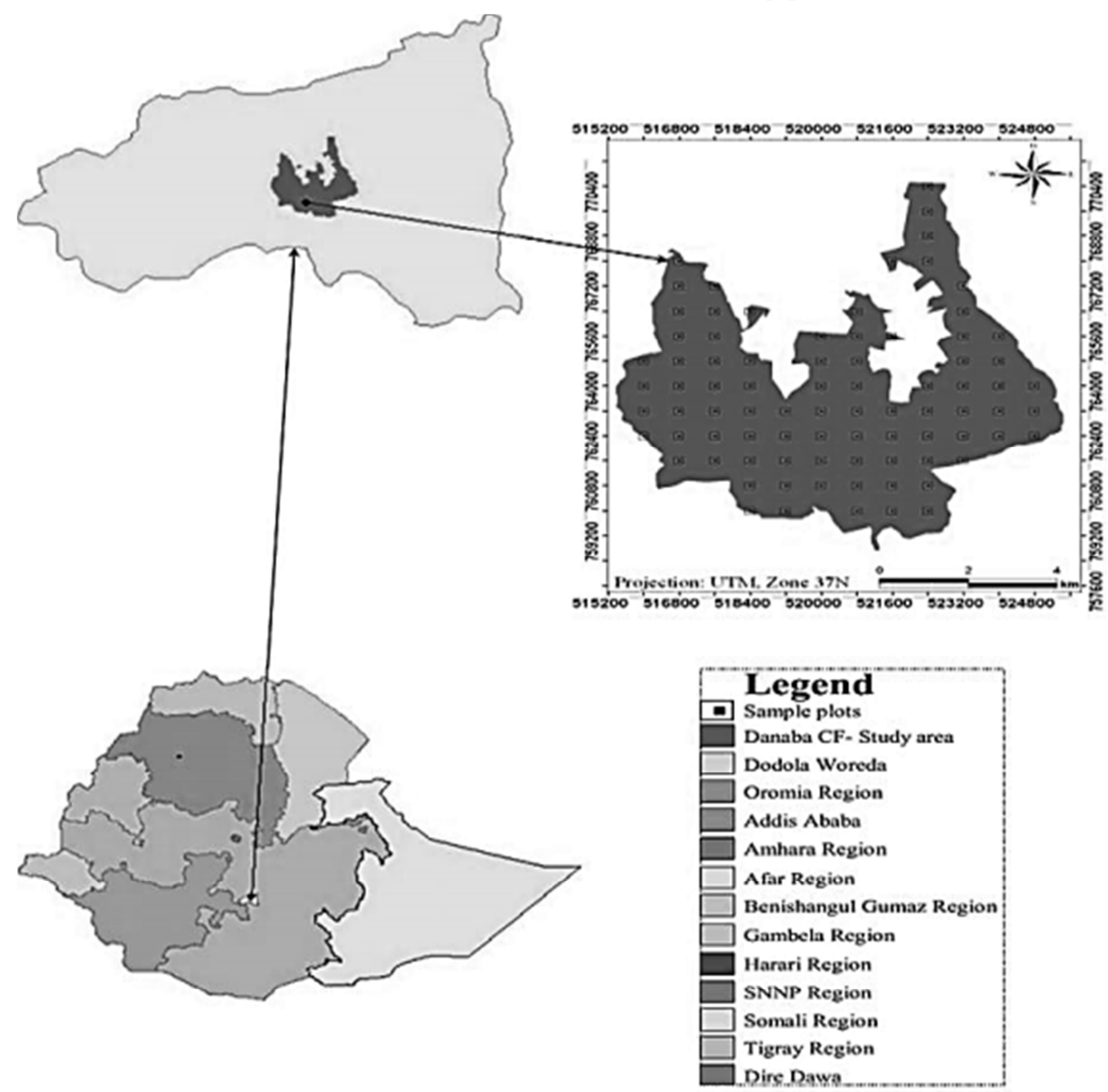

Figure 1. Map of Ethiopia showing Regional States, Danaba CF and location of acquired sample plots. 


\subsection{Sampling Design and Measurements}

The field work for forest inventory was conducted from September 2013 to March 2014. A systematic sampling method was used for identification of sampling points distant $800 \mathrm{~m}$ from each other resulting in a total of 83 intersection points (Figure 1). In each intersection, $20 \mathrm{~m} \times 20 \mathrm{~m}\left(400 \mathrm{~m}^{2}\right.$ equivalent to $0.04 \mathrm{ha}$ ) of plots were established for biomass inventory and identified using GPS in the field.

In each biomass plot, all tree species were identified and had their Diameter at Breast Height $(\mathrm{DBH} \geq 2.5 \mathrm{~cm})$ and height measured using diameter tape and Suunto Hypsometer, respectively. Above-ground biomass calculation for trees used a two-way method: For tress $\geq 5 \mathrm{~cm} \mathrm{DBH,} \mathrm{[6]}$ model was used while trees having between $\geq 2.5 \mathrm{~cm}$ and $<$ $5 \mathrm{~cm}$ DBH (1), an allometric model of biomass and volume tables with species description for community forest management developed by [7] was applied to calculate biomass (2).

$$
\mathrm{Y}=\text { Exp. }\left\{-2.187+0.916 \ln \left(\mathrm{D}^{2} \times \mathrm{H} \times \mathrm{S}\right)\right\}
$$

Where: Y- Above-ground biomass $(\mathrm{kg}), \mathrm{H}-$ Height of tree (m), D- Diameter $(\mathrm{cm})$ at breast height $(1.3 \mathrm{~m})$, and S- Wood density $\left(\mathrm{t} . \mathrm{m}^{-3}\right)$ for specific species [8-10].

$$
\operatorname{Ln}(A G S B)=a+b \ln (D)
$$

Where: AGSB- Above-ground sapling biomass (Kg), a and $b-$ Species specific constants [11, 7], and D - Diameter $(\mathrm{cm})$ at breast height $(1.3 \mathrm{~m})$.

Below-ground biomass of tree species was calculated considering $15 \%$ of the aboveground biomass [12]. The biomass of stock density was converted to carbon stock density by multiplying 0.47 fraction of the [13] default value.

Additionally, at the center of each main plot a $5 \mathrm{~m} \times 5 \mathrm{~m}$ sub-plots were used for shrub species sampling. The species were counted and their samples were uprooted and divided into above- and below-ground through identifying the collar region and fresh weights recorded. A procedure adapted by [14] of the loss on ignition (LOI) method was used to estimate percentage of carbon in shrub species. In this method, initially taken fresh weight of samples was dried at $65^{\circ} \mathrm{C}$ in the oven for 48 hours to take dry weight. Oven dried grind samples were taken $(3.00 \mathrm{~g})$ in pre-weighted crucibles, and then put in the furnace at $550^{\circ} \mathrm{C}$ for one hour to ignite. The crucibles were cooled slowly inside the furnace. After cooling, the crucibles with ash were weighed and percentage of organic carbon was calculated according to [15]. Equation 3 showed below:

$$
\mathrm{A}_{\mathrm{sh}}=\left(\mathrm{W}_{3}-\mathrm{W}_{1}\right) /\left(\mathrm{W}_{2}-\mathrm{W}_{1}\right) \times 100
$$

$\mathrm{C}(\%)=\left(100-\% \mathrm{~A}_{\mathrm{sh}}\right) \times 0.58$ (Considering $58 \%$ carbon in ash-free litter material)

Where: C - Biomass carbon stock, $\mathrm{W}_{1}-$ Weight of crucible, $\mathrm{W}_{2}$ - Weight of the oven-dried grind sample and crucible, and $\mathrm{W}_{3}$ - Weight of ash and crucible.

For sampling of LHGs, a $1 \mathrm{~m} \times 1 \mathrm{~m}$ sub-plots at all corner and middle positions of each main plot were used. LHGs within five $1 \mathrm{~m}^{2}$ quadrats of each main plot were collected and weighed on the field, and $100 \mathrm{~g}$ of evenly mixed subsamples were brought to the laboratory to determine dry biomass and percentage of carbon. To estimate the biomass carbon stock, the sub-samples taken in the field were used to determine an oven-dry-to-wet mass ratio that was used to convert the total wet mass to oven dry mass according to [16]. The amount of biomass per unit area was calculated according to equation 4 :

$$
L H G s=\frac{W_{\text {field }}}{A} * \frac{W_{\text {sub-sample, } d r y}}{W_{\text {sub-sample,wet }}} * \frac{1}{10,000}
$$

Where: LHGs - Biomass of leaf litter, herbs, and grasses $\left(t \cdot a^{-1}\right), W_{\text {field }}-$ Weight of the fresh field sample of leaf litter, herbs, and grasses- destructively sampled within an area of size A (g), A - Size of the area in which leaf litter, herbs, and grasses were collected (ha), $\mathrm{W}_{\text {sub-sample, dry }}$ - Weight of the oven-dry sub-sample of leaf litter, herbs, and grasses taken to the laboratory to determine moisture content $(\mathrm{g})$, and $\mathrm{W}_{\text {sub- }}$ sample, wet - Weight of the fresh sub-sample of leaf litter, herbs, and grasses taken to the laboratory to determine moisture content (g). To determine percent of carbon in LHGs, the loss on ignition (LOI) method of [15] was applied. The carbon density of LHGs was then calculated by multiplying biomass of LHGs per unit area with the percentage of carbon determined for each sample.

For SOC determination, soil samples were collected within five $1 \mathrm{~m}^{2}$ quadrats in which LHGs samples were taken. Soil samples were collected up to $30 \mathrm{~cm}$ in depth (between $0-10$, 10-20 and $20-30 \mathrm{~cm}$ depths) using a calibrated soil auger [13]. A composite sample was obtained by mixing soil from three layers taken from five sub-plots of each main plot in order to determine bulk density and organic carbon concentration. About $150 \mathrm{~g}$ of composite samples were collected from each main plot. To determine SOC, field moist soil were dried in an oven at $105^{\circ} \mathrm{C}$ for 12 hours in laboratory to determine moisture content and dry bulk density. To estimate the percentage of organic carbon, samples were analysed by the wet oxidation method [17]. The carbon stock density of soil organic carbon was calculated as recommended by [16] from the percentage of carbon and bulk density of soil at predetermined depth of the samples were taken.

$$
\text { SOC }=\% C \times \rho \times d
$$

Where:

SOC - Soil organic carbon stock per unit area $\left(\mathrm{t}^{\mathrm{h}} \mathrm{a}^{-1}\right), \% \mathrm{C}$ - Carbon concentration (\%), $\mathrm{d}$ - Soil depth $(\mathrm{cm})$, and $\rho-$ Bulk density $\left(\mathrm{g} \cdot \mathrm{cm}^{-3}\right)$.

The carbon stock is then converted to tons of $\mathrm{CO}_{2}$ equivalent by multiplying it by $44 / 12$ or 3.67 of Molecular weight ratio of $\mathrm{CO}_{2}$ to $\mathrm{O}_{2}$ in order to understand $\mathrm{CO}_{2}$ mitigation potential of the study area. Carbon density in trees, shrubs, LHGs and organic soil were analysed using SPSS statistical software package. 


\section{Results and Discussion}

\subsection{Accumulated Carbon in Tree Species of Danaba CF}

The assessment of [18] and [19] on biome-average tropical forest biomass carbon stock estimates, the average carbon stock of Sub-Saharan Africa, Tropical Asia and Brazilian Amazon forests are 143, 151, 186 t.ha $^{-1}$, respectively. On the other hand the mean biomass carbon stocks of trees in the Natural Forest of Bangladesh is $110.94 \mathrm{t} \cdot \mathrm{ha}^{-1}$ [14] and Community Forest of Mid Hill Region of Nepal is $71.36 \mathrm{t} \cdot \mathrm{ha}^{-}$ ${ }^{1}$ [20]. The current study showed that out of the sixteen major tree species recorded in the study area, Juniperus procera and Podocarpus falcatus stored enormous density of carbon with 179.17 (657.55 $\mathrm{CO}_{2}$ equivalents) (56.1\%) and 105.73 (388.03 $\mathrm{CO}_{2}$ equivalents) $(33.1 \%) \mathrm{t} \cdot \mathrm{ha}^{-1}$, respectively; that amount accounts for approximately $90 \%$ of the Danaba CF carbon stock. The lowest carbon was recorded for Myrsine africana with 0.03 and $0.004 \mathrm{t} \cdot \mathrm{ha}^{-1}$ of above- and belowground carbon stock, respectively (Table 1). Hence, the present study was exceedingly higher than those continental and countries study. Carbon stored in trees above- and belowground was comparable to the previous Ethiopian studies of Egdu Forest [21] and Tara Gedam Forest [22]. The variation might come from variation of age of the trees, existing species and management of the forests. The use of an allometric model for biomass estimation might also help explaining for the difference in estimated value as explained that reliance on allometric equations could be one of the limitations resulting in large variations in such estimates [23].

Table 1. Biomass carbon stock of tree species ( $\left.t . h a^{-1}\right)$

\begin{tabular}{|c|c|c|c|c|c|c|c|c|}
\hline Scientific name & Family & TAGB & TBGB & TB & TAGC & TBGC & TC & $\mathrm{CO}_{2}$ eq \\
\hline Juniperus proceraHochst. Ex Endl. & Cupressaceae & 331.46 & 49.72 & 381.18 & 155.79 & 23.36 & 179.17 & 657.55 \\
\hline Podocarpus falcatus (Thunb.) R. B. ex Mirb. & Podocarpaceae & 195.63 & 29.34 & 224.97 & 91.95 & 13.79 & 105.73 & 388.03 \\
\hline Cupressus lusitanica Miller & Cupressaceae & 23.01 & 3.45 & 26.46 & 10.81 & 1.62 & 12.44 & 45.65 \\
\hline Maytenus arbutifolia (A. Rich.) Wilczek & Celasteraceae & 18.16 & 2.72 & 20.88 & 8.54 & 1.28 & 9.82 & 36.04 \\
\hline Hagenia abyssinica (Bruce) J.F. Gmel. & Rosaceae & 7.44 & 1.12 & 8.56 & 3.50 & 0.52 & 4.02 & 14.75 \\
\hline Eucalyptus globulus Labill. & Myrtaceae & 5.63 & 0.84 & 6.47 & 2.65 & 0.40 & 3.04 & 11.16 \\
\hline Myrsine melanophloeos (L) R. Br. & Myrsinaceae & 5.10 & 0.77 & 5.87 & 2.40 & 0.36 & 2.76 & 10.13 \\
\hline Ilex mitis (L) Radlk & Aquifoliaceae & 1.72 & 0.26 & 1.98 & 0.81 & 0.12 & 0.93 & 3.41 \\
\hline Eucalyptus camaldulensisDehnh. & Myrtaceae & 0.95 & 0.14 & 1.09 & 0.45 & 0.07 & 0.51 & 1.87 \\
\hline Osyris quadripartita Salzm. exDecne. & Santalceae & 0.69 & 0.10 & 0.79 & 0.32 & 0.05 & 0.37 & 1.36 \\
\hline Oncoba spinosa Forssk. & Flacourtiaceae & 0.39 & 0.06 & 0.45 & 0.18 & 0.03 & 0.21 & 0.77 \\
\hline Olea europaea L. & Olacaceae & 0.36 & 0.05 & 0.41 & 0.17 & 0.03 & 0.19 & 0.70 \\
\hline Galiniera saxifraga (Hochst.) Bridson & Rubiaceae & 0.21 & 0.03 & 0.24 & 0.10 & 0.01 & 0.11 & 0.40 \\
\hline Pittosporum viridiflorum Sims & Pittosporaceae & 0.12 & 0.02 & 0.14 & 0.06 & 0.01 & 0.06 & 0.22 \\
\hline Hypericum revolutum Vahl & Hypericaceae & 0.07 & 0.01 & 0.08 & 0.03 & 0.01 & 0.04 & 0.15 \\
\hline Myrsine africana L. & Myrsinaceae & 0.06 & 0.01 & 0.07 & 0.03 & 0.004 & 0.03 & 0.11 \\
\hline
\end{tabular}

TAGB, TBGB - total above- and below-ground biomass respectively; TB- total biomass; TAGC, TBGC- total above- and below-ground carbon respectively; TC- total carbon; eq- equivalents

\subsection{Carbon Store Share within DBH and Height Classes of Tree Species}

Within eight category of DBH classes, 5-20 cm DBH class had the highest density of trees with 401 trees ha $^{-1}$ (41.8\%) while trees with DBH greater than $120 \mathrm{~cm}$ were the least dominant in the study area and consisting of 4 trees $\mathrm{ha}^{-1}$ $(0.5 \%)$. Irrespective of the highest density of DBH class, the highest corresponding carbon reserves were found in $\mathrm{DBH}$ class of $>80-100(25.3 \%),>60-80(20.1 \%)$ and $>100-120$ $(15.8 \%) \mathrm{cm}$ with $80.74, \quad 64.20$ and $50.60 \mathrm{t} \cdot \mathrm{ha}^{-1}$ of corresponding carbon density, respectively. DBH class of $2.5-<5 \mathrm{~cm}$ was the reservoir of least carbon stock in the $\mathrm{CF}$ with $3.65(0.5 \%) \mathrm{t} \cdot \mathrm{ha}^{-1}$ of the total stock density (Figure 2 ). The height of tree species were categorized into eight classes, of which height class of $>10-15 \mathrm{~m}$ had the highest density of 355 trees $\mathrm{ha}^{-1}(34.5 \%)$ while least density of trees were found within the uppermost canopy of trees with $>35 \mathrm{~m}$ of height class by accounting 3 trees $\mathrm{ha}^{-1}(0.3 \%)$. From the mean total mean carbon stock of the study area stored in above- and below-ground biomass of tree species of the study area, the highest carbon reserves were found in height class of $>25-30$ $(25.4 \%),>20-25(23.1 \%)$ and $>15-20(18.8 \%) \mathrm{m}$ with corresponding stock density of 81.27, 73.79 and $59.97 \mathrm{t} \cdot \mathrm{ha}^{-1}$, respectively (Figure 3).

More than $50 \%$ of the trees were found in $<20 \mathrm{~cm} \mathrm{DBH}$ class. Hence, the study showed the forest is dominated by young trees after the implementation of community forest management through plantation and natural regenerations. The ultimate inference indicates that, there is high potential of increasing biomass carbon stock in the future if appropriate management of the forest is implemented. 




Figure 2. Carbon stock distribution within DBH Classes.



Hieght class

Figure 3. Carbon stock distribution within Height Classes.

\subsection{Accumulated Carbon in Shrub Species of Danaba CF}

Among six frequently occurring shrub species of the study area, mean carbon density of $0.40 \pm 0.16\left(1.47 \mathrm{CO}_{2}\right.$ equivalents) t.ha ${ }^{-1}$ was recorded. Conyza hypoleuca and Carissa spinarum were the highest and least store of carbon with $0.18(46.3 \%)$ and $0.03(7.3 \%) t \cdot h^{-1}$, respectively (Table 2). Shrub species of Danaba CF contributed small biomass carbon. Due to huge canopies and observed seasonal plantation of tree species makes unsuitable for shrub species regeneration.

Table 2. Biomass carbon stock of shrub species $\left(t . h a^{-1}\right)$.

\begin{tabular}{|c|c|c|c|c|c|c|c|c|}
\hline Scientific name & Family & TAGB & TBGB & TB & TAGC & TBGC & TC & $\mathrm{CO}_{2}$ eq. \\
\hline Conyza hypoleucaA.Rich. & Asteraceae & 0.30 & 0.15 & 0.45 & 0.13 & 0.05 & 0.18 & 0.66 \\
\hline Maytenus undata (Thunb.) Blakelock & Celastraceae & 0.18 & 0.05 & 0.23 & 0.03 & 0.02 & 0.06 & 0.22 \\
\hline Rosa abyssinica Lindley & Rosaceae & 0.09 & 0.02 & 0.11 & 0.04 & 0.01 & 0.05 & 0.18 \\
\hline Dovyalis abyssinica (A.Rich) Warb. & Flacourtiaceae & 0.08 & 0.02 & 0.10 & 0.03 & 0.01 & 0.04 & 0.15 \\
\hline Erica arborea L. & Ericaceae & 0.07 & 0.01 & 0.08 & 0.03 & 0.01 & 0.04 & 0.15 \\
\hline Carissa spinarum L. & Apocynaceae & 0.08 & 0.03 & 0.11 & 0.02 & 0.01 & 0.03 & 0.11 \\
\hline
\end{tabular}

TAGB, TBGB - total above- and below-ground biomass respectively; TB- total biomass; TAGC, TBGC- total above- and below-ground carbon respectively; $\mathrm{TC}$ - total carbon; eq- equivalents 


\subsection{Accumulated Carbon in LHGs and Organic Soil}

LHGs biomass carbon shared small amount of carbon in the CF. The assessment on mean litter carbon of tropical forests varies between $2.6-3.8 \mathrm{t} \cdot \mathrm{ha}^{-1}$ as reported by [24] and $2-16$ t.ha $^{-1}$ by [18]. In current inventory of Danaba CF, mean value of $1.06 \pm 0.31 \mathrm{t} \cdot \mathrm{ha}^{-1}$ carbon density with highest store seems to be in grasses. Hence, $3.89 \mathrm{t} \cdot \mathrm{ha}^{-1}$ of $\mathrm{CO}_{2}$ equivalents were stored in LHGs biomass. The result was lower than those ranges. The mean stock density was also lower than most previous studied of Ethiopian forest. The reason for the small carbon stock of LHGs is due to huge closed canopies of $J$. procera and P. falcatus up to the near ground making the growth of herbs and grasses unsuitable. This dominance with evergreen tree species of Danaba CF has also contributed for the existence of small litter falls. As the study area had mountainous manifestation, litter run off occurred and might cause for small carbon account in this pool.

The average bulk density of soil in the CF was estimated to be $0.937 \pm 0.0535 \mathrm{~g} . \mathrm{cm}^{-3}$. The percentages of carbon content of the soil in the study area ranges from $2.27-15.85 \%$ with mean value of $6.38 \pm 2.6764 \%$. Thus, the current average soil organic carbon investigated in the study area was found to be $186.40 \pm 76.5465 \mathrm{t} \cdot \mathrm{ha}^{-1}$. Accordingly, the study area could possibly store $684.088 \mathrm{t} \cdot \mathrm{ha}^{-1}$ of $\mathrm{CO}_{2}$ equivalents within organic soil. SOC estimates of Afromontane rain forests varies between 252 and $581 \mathrm{t} \cdot \mathrm{ha}^{-1}$ [25]. The result of present study was lower than this range. Besides, the value was also lower than that of dry Afromontane Tara Gedam [23] and Egdu Forests [21] of Ethiopia. Rainfall and temperature variation of the studies might have contribution for this variation. Mountainous manifestation of the study area might cause early run off litter, herbs and grasses which in turn contributed for soil organic matter in decomposition.

The SOC share was varied at different soil depths. Table 3 showed the variation of SOC among different soil profile. The average bulk density of the study area increased with depth increment. The mean values of bulk density from top, middle and deep soil profile were $0.82,0.96$ and $0.99 \mathrm{~g} . \mathrm{cm}^{-3}$, respectively; however, SOC decreased with depth increment. The pattern indicates that soil carbon decreased significantly with soil depth which revealed major trends in carbon accumulation which shows that it is found in the upper soil layers (Table 3). This may be due to the accumulation and rapid decomposition of forest litter in the top soil. [14, 26,
27] found that more SOC was stocked at the soil depth of 0 $14 \mathrm{~cm}$. Therefore, the result was in high conformity with those findings.

Table 3. Soil organic carbon stock at different soil depths.

\begin{tabular}{llll}
\hline $\begin{array}{l}\text { Depth of } \\
\text { soil }(\mathbf{c m})\end{array}$ & $\begin{array}{l}\text { Bulk density } \\
\left.\mathbf{( g . c m}^{-3}\right)\end{array}$ & $\begin{array}{l}\text { Organic carbon } \\
\mathbf{( \% )}\end{array}$ & $\begin{array}{l}\text { SOC (t.ha } \\
\mathbf{1} \mathbf{. d e p t h}^{-\mathbf{1}} \mathbf{)}\end{array}$ \\
\hline $0-10$ & $0.82 \pm 0.101$ & $11.70 \pm 3.243$ & $95.01 \pm 15.550$ \\
$10-20$ & $0.96 \pm 0.162$ & $6.35 \pm 3.182$ & $59.34 \pm 12.441$ \\
$20-30$ & $0.99 \pm 0.151$ & $5.42 \pm 2.549$ & $52.11 \pm 13.893$ \\
F & 6.61 & 19.05 & 11.87 \\
P & $0.0032 * *$ & $0.0000^{* *}$ & $0.0001 * *$ \\
\hline
\end{tabular}

** Values significant at $\alpha=0.05$ (95\%); SOC- Soil Organic Carbon

Thus, this study showed that the carbon density of trees, shrubs, LHGs and organic soil were found to be 319.43 (1172.31 CO $\mathrm{CO}_{2}$ eq.), 0.40 (1.47 $\mathrm{CO}_{2}$ eq.), 1.06 (3.89 $\mathrm{CO}_{2}$ eq.) and 186.40 (684.09 $\mathrm{CO}_{2}$ eq.) $\mathrm{t} \cdot \mathrm{ha}^{-1}$, respectively. Hence, in the current study the total carbon stock in Danaba CF was 507.29 (1861.75 $\mathrm{CO}_{2}$ eq.) $t \cdot \mathrm{ha}^{-1}$ (Table 4). Accordingly, the maximum quantity of carbon stock was found in tree species with reservoir of $63 \%$ of the total carbon. The forest soil organic carbon ranked the second reservoir of carbon which has accumulated $36.7 \%$ of the total carbon in the study area. Shrubs and LHGs' biomass contributes small amount of carbon; stored only 0.1 and $0.2 \%$ of the total carbon, respectively (Figure 4).

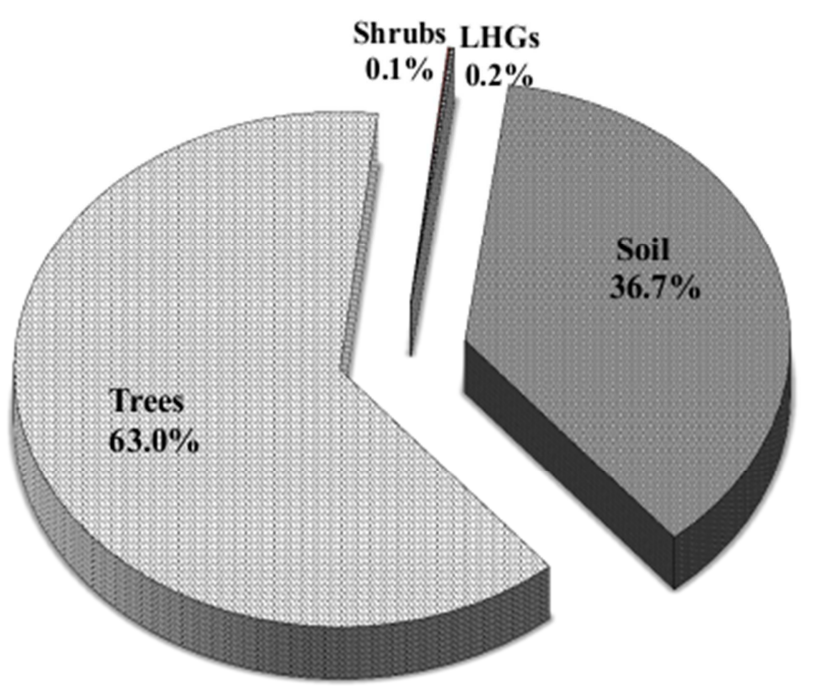

Figure 4. Carbon stock percentage in different forest strata.

Table 4. Total reserved carbon (t.ha $\left.{ }^{-1}\right)$ in Danaba CF of Oromia Regional State, Ethiopia in 2014.

\begin{tabular}{lllllllll}
\hline Carbon pools & TAGB & TBGB & TB & TAGC & TBGC & C(LHGs) & SOC & TC \\
\hline Trees & 591.00 & 88.65 & 679.65 & 277.78 & 41.65 & & & \\
Shrubs & 0.80 & 0.28 & 1.08 & 0.29 & 0.11 & & & \\
LHGs & & & & & & & 1.06 & 186.40 \\
Soil & & & & & & & 1.06 & 186.40 \\
Total & 591.80 & 88.93 & 680.73 & 278.03 & 41.76 & 507.29 \\
\hline
\end{tabular}

TAGB, TBGB- total above- and below-ground biomass respectively; TB- total biomass; TAGC, TBGC- total above- and below-ground carbon respectively; C(LHGs) - Litter, herbs and grasses biomass carbon; SOC - soil organic carbon; TC - total carbon 


\section{Conclusion}

As a conclusion, we observed that tree species sequestered the highest carbon of all carbon pools and J. procera reserved the highest biomass carbon. Undergrowth shrubs, LHGs and organic soil were also important pools that contributed for carbon sink in the CF. Danaba CF was the reservoir of potentially high amount of carbon compared to similar areas in the tropics particularly in tropical Africa, Asia and Latin America. Currently, the CF had the capacity to store 507.29 $\mathrm{t} \cdot \mathrm{ha}^{-1}$ carbon; helping in sequestering $1861.75 \mathrm{t} \cdot \mathrm{ha}^{-1}$ of $\mathrm{CO}_{2}$ equivalents which implies that remarkable carbon finance benefit has to be demanded. The carbon sequestration should be integrated with Reduced Emission from Deforestation and Degradation (REDD+) and Clean Development Mechanism (CDM) carbon trading system of the Kyoto Protocol to get monetary benefit of carbon dioxide mitigation which can be helpful for the sustainability of the forest.

\section{Acknowledgements}

The authors acknowledge Addis Ababa University, Dilla University, Wondo Genet College of Forestry and Natural Resources, Oromia Forest and Wildlife Enterprise and Ethiopian National Meteorology Agency, for the assistance during research period. Fund was obtained from the Thematic Research of Addis Ababa University; "Floral and Fungal Diversity, Ethnobotany and Carbon Sequestration Potential of Western and Southwestern Forests of Ethiopia".

\section{References}

[1] E. Sundquist, B. Robert, F. Stephen, G. Robert, H. Jennifer, K. Yousif, T. Larry, and W. Mark, "Carbon Sequestration to Mitigate Climate Change", USA, New York: U.S. Geological Survey, pp. 1-4, 2008.

[2] FAO, "Global Forest Resource Assessment", Rome Italy: FAO, Main report, Forest paper 103, 2010.

[3] Saatchi, S.M., Harris, S., Brown, M., Lefsky, E., Mitchard, W., Salas, B., Zutta, W., Buermann, S., Lewis, S., Hagen, S., Petrova, L., White, M., and Silman, A., "Benchmark map of carbon forest carbon stocks in tropical regions across three continents", Proceedings of the Natural of Academy Science, 108(24), 9899-9904, 2011.

[4] World Bank, "Convenient solutions to an inconvenient truth: Ecosystem-based approaches to climate change", Washington D.C.:World Bank, 19 pp, 2009.

[5] Digital soil and terrain data base of East Africa, "Soil and Terrain Database for Northeastern Africa",Rome, Italy: Food and Agricultural Organization of the United Nations, 1997.

[6] Chave, J., Andalo, C., Brown, S., Cairns, M., Chambers, J., Eamus, D., Folster, H., Fromard, F., Higuchi, N., and Kira T., 2005,"Tree allometry and improved estimation of carbon stocks and balance in tropical forests", Oecologia, 145, 87-99.
[7] P.R. Tamrakar, "Biomass and Volume Tables with Species Description for Community Forest Management", Kathmandu, Nepal: Ministry of Forest and Soil Conservation, 2000 .

[8] Morales, J.B., "Wood specific gravity from two tropical forests in Mexico",IAWA Bulletin New Series, 8(2), 143-148, 1987.

[9] G. Reyes, S. Brown, J. Chapman, and A.E., "Wood Density of Tropical Tree Species", New Orleans, Louisiana, Winrock International, Southern Research Station: USDA Forest Service Publication, pp. 10-30, 1992.

[10] IPCC, "Good Practice Guidance for Land Use, Land Use Change and Forestry, J. Penman, M. Gytarsky, T. Hiraishi, T. Krug, D. Kruger, R. Pipatti, L. Buendia, K. Miwa, T. Ngara, K. Tanabe, and F. Wagner", Eds. Hayama, Japan: IPCC National Greenhouse Gas Inventories Programme, Institute for Global Environmental Strategies, 2003.

[11] E.R. Sharma, and J. Pukkala, "Volume Tables for Forest Trees of Nepal", Kathmandu, Nepal: Ministry of Forest and Soil Conservation, 84 pp, 1990.

[12] K.G. MacDicken, "A Guide to Monitoring Carbon Storage in Forestry and Agroforestry Projects", Arlington, Virginia: Forest Carbon Monitoring Program Winrock International Institute for Agricultural Development, 84 pp, 1997.

[13] IPCC, "Guidelines for National Greenhouse Gas Inventories",Hayama, Japan: National Greenhouse Gas Inventories Program, Institute for Global Environmental Strategies Publishing, No. 4, 2006.

[14] Ullah, M.R., and Al-Amin M., "Above- and below-ground carbon stock estimation in a natural forest of Bangladesh", Journal of Forest Science, 58(8), 372-379, 2012.

[15] S.E. Allen, H.M. Grimshaw, and A.P. Rowland, "Chemical analysis, In: Methods in Plant Ecology, P.D. Moore, and S.B. Chapman", Eds. Boston, USA: Blackwell Scientific Publications, pp. 285-300, 1986.

[16] T. Pearson, S. Walker, and S. Brown, "Sourcebook for Landuse, Land-use Change and Forestry Projects", Arlington, USA: Winrock International and the Bio-carbon Fund of the World Bank, pp. 18-35, 2005.

[17] S.M.I. Huq, and M.D. Alam, "A Handbook on Analyses of Soil, Plant and Water", Bangladesh: BACER-DU, University of Dhaka, 246 pp., 2005.

[18] S. Brown, "Estimating Biomass and Biomass Change of Tropical Forests", Rome, Italy: A primer, pp. 20-55, 1997.

[19] Achard, F., Eva, H.D., Mayaux, P., Stibig, H.J., and Belward, A.,"Improved estimates of net carbon emissions from land cover change in the tropics for the 1990s Glob",Biogeochem. Cycles, 18, 1029-42, 2004.

[20] Anup, K.C., Bhandari, G., Joshi, G.R., and Aryal, S.,"Climate change mitigation potential from carbon sequestration of community forest in mid hill region of Nepal", International Journal of Environmental Protection, 3(7), 33-40, 2013.

[21] Adugna, F., Teshome, S., and Mekuria, A., "Forest carbon stocks and variations along altitudinal gradients in Egdu Forest: Implications of managing forests for climate change mitigation", Science, Technology and Arts Research Journal, 2(4), 40-46, 2013. 
[22] Mohammed, G., Teshome, S., and Satishkumar, B., "Forest carbon stocks in woody plants of Tara Gedam forest: Implication for climate change mitigation", Science, Technology and Arts Research Journal, 3(1), 101-107, 2014.

[23] R.d.Lasco, F.B. Pulhin, R.G. Visco, D.A. Racelis, I.Q. Guillermo, and R.F. Sales, "Carbon stocks assessment of Philippine forest ecosystems", Philips, Bogor, pp. 28-29, 2000 .

[24] Brown, S., and Lugo, A.E., "The storage and production of organic matter in tropical forests and their role in the global carbon cycle",Biotropical, 14, 161-187, 1982.

[25] Munishi, P.K., and Shear, T., "Carbon storage of two afromontane rain forests in the eastern arc mountains of Tanzania", Journal of Tropical Forest Science, 16(1), 78-93, 2014.

[26] Mendoza-Vega, J., Karltun, E., and Olsson M., "Estimations of amounts of soil organic carbon and fine root carbon in land use and land cover classes, and soil types of Chiapas highlands, Mexico", Forest Ecology Management, 177, 191206, 2003.

[27] Chowdhury, M.S.H., Biswas, S., Halim, M.A., Haque, S.M.S., Muhammed, N., and Koike M., "Comparative analysis of some selected macronutrients of soil in orange orchard and degraded forests in Chittagong hill tracts, Bangladesh", Journal of Forest Science, 1, 27-30, 2007. 